\title{
Nocardia altamirensis sp. nov., isolated from Altamira cave, Cantabria, Spain
}

\author{
Valme Jurado, ${ }^{1}$ Patrick Boiron, ${ }^{2,3,4}$ Reiner M. Kroppenstedt, ${ }^{5}$ \\ Frédéric Laurent, ${ }^{2,3,4}$ Andrée Couble, ${ }^{2,3,4}$ Leonila Laiz, ${ }^{1}$ \\ Hans-Peter Klenk, ${ }^{5}$ Juan M. González, ${ }^{1}$ Cesareo Saiz-Jimenez, ${ }^{1}$ \\ Delphine Mouniée, 2,3,4 Emanuelle Bergeron ${ }^{2,3,4}$ \\ and Verónica Rodríguez-Nava ${ }^{2,3,4}$
}

Correspondence Verónica Rodríguez-Nava veronica.rodriguez@ sante.univ-lyon 1.fr

\author{
${ }^{1}$ Instituto de Recursos Naturales y Agrobiologia, CSIC, Apartado 1052, E-41080 Sevilla, Spain \\ ${ }^{2}$ Research group on 'Bacterial Opportunistic Pathogens and Environment', Université de Lyon, \\ F-69003 Lyon, France \\ ${ }^{3}$ Université Lyon 1 and CNRS, UMR 5557, Ecologie Microbienne, F-69622 Villeurbanne, France \\ ${ }^{4}$ Institut des Sciences Pharmaceutiques et Biologiques and Observatoire Français des Nocardioses, \\ F-69373 Lyon, France \\ ${ }^{5}$ Deutsche Sammlung von Mikroorganismen und Zellkulturen, D-38124 Braunschweig, Germany
}

\begin{abstract}
A novel actinomycete strain, OFN S17 ${ }^{\top}$, was isolated from a sample collected from Altamira Cave, Cantabria, Spain. This strain was identified by using a polyphasic taxonomic approach. The $16 \mathrm{~S}$ rRNA, hsp65 and sod gene sequences of the strain were determined and compared with those of representative Nocardia species. The results showed that strain OFN $S 17^{\top}$ should be assigned to the genus Nocardia. Phylogenetic analysis indicated that strain OFN S17 $7^{\top}$ was most closely related to the type strain of Nocardia tenerifensis (98.6, 96.2 and $96 \%$ similarity, respectively, for the $16 \mathrm{~S}$ rRNA, $h s p 65$ and sod gene sequences). The DNA G $+\mathrm{C}$ content was $64.4 \mathrm{~mol} \%$. DNA-DNA hybridization analyses revealed $29 \%$ relative reassociation between the DNA of strain OFN S17 $7^{\top}$ and $N$. tenerifensis DSM $44704^{\top}$. The phenotypic and genotypic data show that strain OFN S17 $7^{\top}$ merits recognition as a representative of a novel species of the genus Nocardia, for which the name Nocardia altamirensis sp. nov. is proposed. The type strain is OFN S17 ${ }^{\top}$ (= CIP $109606^{\top}=$ DSM $\left.44997^{\top}\right)$.
\end{abstract}

Members of the genus Nocardia are aerobic, Gram-positive bacteria that are ubiquitous in the environment and can be found worldwide as saprophytic components in fresh and salt water, soil, dust, decaying vegetation and decaying faecal deposits from animals (Brown-Elliott et al., 2006). The application of polyphasic taxonomic procedures has led to marked improvements in the classification of the genus Nocardia (Goodfellow, 1998). Numerous novel species have been described in recent years by using $16 \mathrm{~S}$ rRNA gene sequencing as the reference method; at the time of writing, the genus encompasses 70 species with validly published names (http://www.bacterio.cict.fr/qr/nocardia. html). It seems likely that the soil is the primary reservoir

The GenBank/EMBL/DDBJ accession numbers for the $16 \mathrm{~S}$ rRNA, hsp65 and sod gene sequences of strain OFN S17 ${ }^{\top}$ are respectively EU006090, EU007653 and EU432372.

Neighbour-joining trees based on sequences of the 16S rRNA (with an extended set of reference sequences), hsp65 and sod genes are available as supplementary material with the online version of this paper. of nocardiae, although members of the genus are better known as causal agents of suppurative and granulomatous infections of humans and animals (McNeil \& Brown, 1994). There is also evidence that nocardial species diversity in both non-extreme and extreme habitats is grossly underestimated (Orchard \& Goodfellow, 1980). Investigations of bacterial biodiversity from natural caves have revealed the presence of several novel actinomycetes (Groth \& Saiz-Jimenez, 1999; Groth et al., 1999, 2002; Jurado et al., 2005a, b, 2006; Lee, 2006a, b, c). This is illustrated by the recent description of Nocardia jejuensis and Nocardia speluncae from natural caves in South Korea (Lee, 2006b; Seo et al., 2007). In a preliminary report, Groth \& Saiz-Jimenez (1999) investigated the presence of actinomycetes in Altamira and Tito Bustillo caves. Approximately 350 actinomycetes were identified by morphological, physiological and chemotaxonomic methods, among which the genus Nocardia was well represented. 
In this work, a polyphasic approach was used to determine the taxonomic position of bacterial strain OFN S17 ${ }^{\mathrm{T}}$. This strain was retrieved from Altamira cave (Cantabria, Spain) as a member of a complex microbial community forming a grey-coloured colonization on the walls of the cave.

Strain OFN $S 17^{\mathrm{T}}$ was isolated on tryptose soy agar (TSA; Oxoid) at $28{ }^{\circ} \mathrm{C}$. This strain was examined for a broad range of biochemical properties. The cultural characteristics of strain OFN $S 17^{\mathrm{T}}$ was determined on Bennett's agar after 10 days at $30{ }^{\circ} \mathrm{C}$. The well-developed substrate mycelium was yellowish orange in colour with irregular branches penetrating the agar, while the aerial hyphae were white. On Bennett's agar, the isolate was able to grow at $25-37{ }^{\circ} \mathrm{C}$. The bacterial cells were Gram-positive and slightly acid-fast in a modified Ziehl-Neelsen method ( $1 \%$ acid decoloration). Phenotypic characteristics were determined for strain OFN $S 17^{\mathrm{T}}$ and the type strains of the closely related species Nocardia tenerifensis (DSM $44704^{\mathrm{T}}$ ) and Nocardia brasiliensis (ATCC $19296^{\mathrm{T}}$ ). Catalase activity, urea hydrolysis and the ability to hydrolyse adenine, casein, hypoxanthine, tyrosine, uric acid and testosterone were examined by following the protocol of Boiron et al. (1993). Tests for the utilization of various substrates as sole carbon sources (at $1 \%, \mathrm{w} / \mathrm{v}$ ) were carried out using previously described methods (Goodfellow \& Lechevalier, 1989; Goodfellow, 1992, 1998) and utilization was observed over a period of 2 weeks. The more relevant results that allow discrimination between strain OFN $\mathrm{S}_{1} 7^{\mathrm{T}}$ and the type strains of $N$. brasiliensis and $N$. tenerifensis are the inability of strain OFN S17 $7^{\mathrm{T}}$ to utilize L-arabinose and its ability to decompose uric acid. The complete phenotypic results from strain OFN $S 17^{\mathrm{T}}$ and the two reference type strains are summarized in Table 1.

Extraction of genomic DNA, PCR amplification and sequencing of the 16S RNA, hsp65 and sod genes were carried out as described by Rodríguez-Nava et al. (2004, 2006). Sequence analysis was performed using an Applied Biosystems model 373A DNA sequencer. Overlapping DNA segments from the forward and reverse strands were analysed to determine a consensus sequence for each gene. The nearly complete $16 \mathrm{~S}$ rRNA gene sequence for strain OFN S17 ${ }^{\mathrm{T}}$ (1348 nt; corresponding to positions $46-1400$ of the Escherichia coli numbering system) was obtained by using primers SQ1 and SQ6 (Rodríguez-Nava et al., 2004). The hsp65 and sod genes of strain OFN $S 17^{\mathrm{T}}$ were partially amplified (around $441 \mathrm{nt}$ for each gene) by using primers TB11 and TB12 for hsp65 and Z205 and Z212 for sod, as described by Rodríguez-Nava et al. (2006, 2007). For phylogenetic analysis, nucleotide sequences were aligned using the program CLUSTAL_X (Thompson et al., 1997) with the corresponding sequences of representative Nocardia species from the GenBank and BIBI (Devulder et al., 2003) databases. Phylogenetic trees were reconstructed by using the software packages MEGA (Kumar et al., 2004) and PHYLO_WIN (Galtier et al., 1996). The overall topologies of phylogenetic trees obtained by the neighbour-joining (Saitou \& Nei, 1987), maximum-likelihood (Felsenstein,
Table 1. Phenotypic characteristics that differentiate strain OFN $S 17^{\top}$ from the type strains of $N$. tenerifensis and $N$. brasiliensis

Strains: $1, N$. altamirensis sp. nov. OFN S17 ${ }^{\mathrm{T}} ; 2, N$. tenerifensis DSM $44704^{\mathrm{T}} ; 3$, N. brasiliensis ATCC $19296^{\mathrm{T}}$. All three strains were positive in tests for growth on D-fructose, D-galactose, D-glucose, glycerol, mannose and D-ribose (all at $1.0 \%, \mathrm{w} / \mathrm{v}$ ), urea hydrolysis, degradation of casein, activity of catalase and growth on Bennett's agar at $25{ }^{\circ} \mathrm{C}$ and negative for growth on raffinose $(1.0 \%, \mathrm{w} / \mathrm{v}) .-$, Negative; + , positive; $\mathrm{w}$, weakly positive.

\begin{tabular}{|lccc|}
\hline Test & $\mathbf{1}$ & $\mathbf{2}$ & $\mathbf{3}$ \\
\hline Growth on carbon sources $(\%, \mathrm{w} / \mathrm{v})$ & & & \\
L-Arabinose $(1.0)$ & - & + & + \\
D-Mannitol (1.0) & + & + & $\mathrm{W}$ \\
L-Rhamnose (1.0) & - & $\mathrm{W}$ & - \\
Sucrose $(1.0)$ & - & - & + \\
Sorbitol $(1.0)$ & - & $\mathrm{W}$ & - \\
Growth on Bennett's agar at: & & & \\
$37^{\circ} \mathrm{C}$ & $\mathrm{W}$ & + & + \\
$45^{\circ} \mathrm{C}$ & - & - & + \\
Decomposition of $(\%$, w/v): & & & \\
Adenine $(0.4)$ & - & + & - \\
Hypoxanthine $(0.4)$ & $\mathrm{W}$ & $\mathrm{W}$ & + \\
Testosterone $(0.1)$ & + & + & $\mathrm{W}$ \\
Tyrosine $(0.5)$ & $\mathrm{W}$ & - & + \\
Uric acid $(0.5)$ & + & - & - \\
\hline
\end{tabular}

1981) and maximum-parsimony (Kluge \& Farris, 1969) methods were similar (data not shown). The robustness of the trees was assessed by bootstrap resampling (1000 replicates).

The results of our phylogenetic analysis showed that strain OFN $S 17^{\mathrm{T}}$ fell within the evolutionary radiation encompassed by the genus Nocardia. According to 16S rRNA gene sequence similarity calculations, strain OFN $S 17^{\mathrm{T}}$ was most closely related to N. brasiliensis ATCC $19296^{\mathrm{T}}$ (98.67\% sequence similarity; 18 differences out of $1348 \mathrm{nt}$ ) and $N$. tenerifensis GW39-1573 ${ }^{\mathrm{T}}$ (98.60 \% sequence similarity; 19 differences out of $1348 \mathrm{nt}$ ). In the phylogenetic tree based on the 16S rRNA gene sequence (Fig. 1 and Supplementary Fig. S1, available in IJSEM Online), strain OFN S17 $7^{\mathrm{T}}$ forms a clade with the type strains of $N$. brasiliensis and $N$. tenerifensis that is supported by a bootstrap value of $77 \%$ in the neighbour-joining analysis. The 16S rRNA gene sequence similarity between our strain and the type strains of $N$. brasiliensis and $N$. tenerifensis was almost identical, so we decided to extend our study to the hsp65 and sod genes.

For the $h s p 65$ gene, strain OFN $S 17^{\mathrm{T}}$ was more closely related to $N$. tenerifensis DSM $44704^{\mathrm{T}}$, showing $96.2 \%$ sequence similarity (15 differences among $401 \mathrm{nt}$, excluding the primers), than to N. brasiliensis ATCC $19296^{\mathrm{T}}$, which showed only $95.7 \%$ sequence similarity (17 differences among $401 \mathrm{nt}$, excluding the primers). The phylogenetic tree reconstructed from $h s p 65$ gene sequences 


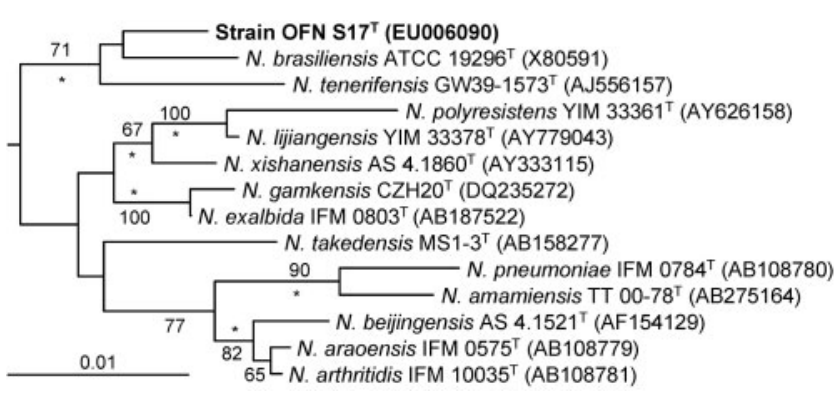

Fig. 1. Phylogenetic tree derived from $16 \mathrm{~S}$ rRNA gene sequences showing the relationships between Nocardia altamirensis sp. nov. OFN S1 $7^{\top}$ and species belonging to the genus Nocardia. The tree was constructed by using the neighbour-joining method and was based on a comparison of 1348 nucleotides. Bootstrap values are expressed as percentages of 1000 replications. Asterisks indicate branches of the tree that were also recovered using maximumlikelihood and maximum-parsimony treeing algorithms. Bar, 0.01 substitutions per nucleotide position. An extended version of this tree including a wider selection of reference strains is available as Supplementary Fig. S1.

did not contain the clade encompassing our isolate and $N$. tenerifensis and $N$. brasiliensis previously observed with the $16 S$ rRNA gene tree (Supplementary Fig. S2). Instead, the clades formed with OFN $S 17^{\mathrm{T}}$ showed non-significant bootstrap values $(<50 \%)$, meaning that these phylogenetic relationships are very weak.

For the sod gene, strain OFN S17 ${ }^{\mathrm{T}}$ was also more closely related to $N$. tenerifensis DSM $44704^{\mathrm{T}}$, showing $96 \%$ sequence similarity (16 differences among $406 \mathrm{nt}$, excluding the primers), than to $N$. brasiliensis ATCC $19296^{\mathrm{T}}$, which showed $95.3 \%$ sequence similarity (19 differences among $406 \mathrm{nt}$, excluding the primers). Similar to the $16 \mathrm{~S}$ rRNA gene, in the phylogenetic tree reconstructed from the sod gene sequence, strain OFN S17 ${ }^{\mathrm{T}}$ forms a clade with the type strains of $N$. tenerifensis and $N$. brasiliensis and, in this case, the clade is supported by a bootstrap value of $92 \%$ in the neighbour-joining analysis (Supplementary Fig. S3).

Phylogenetic analysis of $h s p 65$ and sod gene sequences showed that isolate OFN S17 ${ }^{\mathrm{T}}$ was more closely related to $N$. tenerifensis DSM $44704^{\mathrm{T}}$ than to $N$. brasiliensis ATCC $19296^{\mathrm{T}}$. In light of these results, we decided that it was more pertinent to perform DNA-DNA hybridization between OFN S17 ${ }^{\mathrm{T}}$ and N. tenerifensis DSM $44704^{\mathrm{T}}$.

The degree of DNA-DNA relatedness between strain OFN $\mathrm{S}_{1}{ }^{\mathrm{T}}$ and $N$. tenerifensis DSM $44704^{\mathrm{T}}$ was determined by the fluorometric method as described by Gonzalez \& SaizJimenez (2005). This method measures the divergence between the thermal denaturation midpoint of homoduplex DNA and heteroduplex DNA $\left(\Delta T_{\mathrm{m}}\right)$ using a realtime PCR thermocycler that obtains fluorescence determinations. The degree of DNA-DNA relatedness was also determined using the digoxigenin labelling/antibody detection system described by Ziemke et al. (1998). DNA was labelled and detected colorimetrically with $p$-nitrophenyl phosphate as substrate. Chromosomal DNA was extracted following the method described by Marmur (1961).

The difference in melting temperature between genomic DNA from strain OFN $S 17^{\mathrm{T}}$ and $N$. tenerifensis DSM $44704^{\mathrm{T}}$ was $7{ }^{\circ} \mathrm{C}$. This is above the $5{ }^{\circ} \mathrm{C}$ cut-off point recommended for the delineation of species by Stackebrandt \& Goebel (1994). Using DNA from strain OFN S17 ${ }^{\mathrm{T}}$ as a labelled probe, N. tenerifensis DSM $44704^{\mathrm{T}}$ and strain OFN S17 ${ }^{\mathrm{T}}$ showed $29 \%$ DNA relatedness. The DNA-DNA relatedness results confirmed that strain $S 17^{\mathrm{T}}$ represents a novel genospecies clearly differentiated from N. tenerifensis.

The $\mathrm{G}+\mathrm{C}$ content of genomic DNA of strain OFN S17 was $64.4 \mathrm{~mol} \%$, as determined by the fluorometric method described by Gonzalez \& Saiz-Jimenez (2002).

Strain OFN $S 17^{\mathrm{T}}$ was analysed chemotaxonomically by using the following procedures. The isomer of diaminopimelic acid was analysed by TLC of whole-organism hydrolysates as described by Boiron et al. (1993). Wholecell sugars were analysed following the methods of Staneck \& Roberts (1974). Standard procedures (Kroppenstedt, 1982, 1985; Minnikin et al., 1975, 1984) were used for analyses of fatty acids, mycolic acids and isoprenoid quinones by HPLC and analysed with the standard Microbial Identification System (MIDI) for automated GC analyses. The results support the assignment of strain OFN S17 ${ }^{\mathrm{T}}$ to the genus Nocardia. Analysis of the cell wall revealed mycolic acids with a chain length of 52-58 carbon atoms. Strain OFN S17 ${ }^{\mathrm{T}}$ presented mainly hexahydrogenated menaquinone with eight isoprene units where the two end units are cyclized [MK-8 $\left.\left(\mathrm{H} 4_{\infty-\mathrm{cycl}}\right)\right]$. This menaquinone is observed only in members of the genera Nocardia and Skermania. The isolate contained mainly straight-chain saturated and unsaturated fatty acids including palmitic acid $\left(\mathrm{C}_{16: 0} ; 33.48 \%\right)$, oleic acid $\left(\mathrm{C}_{18: 1} ; 18.40 \%\right)$, palmitoleic acid $\left(\mathrm{C}_{16: 1} ; 15.93 \%\right)$ and tuberculostearic acid (10methyl $\left.\mathrm{C}_{18: 0} ; 13.09 \%\right)$.

It is clear from the genotypic and phenotypic data obtained that strain OFN $S 17^{\mathrm{T}}$ represents a novel species of the genus Nocardia, for which the name Nocardia altamirensis sp. nov. is proposed.

\section{Description of Nocardia altamirensis sp. nov.}

Nocardia altamirensis (al.ta.mi.ren'sis. N.L. fem. adj. altamirensis referring to Altamira cave, Cantabria, Spain, where the type strain was isolated).

Aerobic, Gram-positive, slightly acid-alcohol-fast, catalasepositive, non-motile actinomycete that forms a branched substrate mycelium which fragments into irregular rodshaped to coccoid elements. The colour of the substrate mycelium is yellowish-orange. The aerial mycelium is white and has a patchy distribution. Colonies are $2-3 \mathrm{~mm}$ in diameter on Bennett's agar. Grows well at $30{ }^{\circ} \mathrm{C}$ but does not grow at $45^{\circ} \mathrm{C}$. D-Fructose, D-galactose, D-glucose, 
glycerol, D-mannitol, D-mannose and ribose can be utilized as carbon sources, while raffinose, L-rhamnose, sucrose and sorbitol cannot be utilized. Urea is hydrolysed. Substrates that are decomposed are indicated in Table 1. Major fatty acids are $\mathrm{C}_{16: 0}(33.48 \%), \mathrm{C}_{18: 1}(18.40 \%)$ and tuberculostearic acid (10-methyl $\left.\mathrm{C}_{18: 0} ; 13.09 \%\right)$. The mycolic acids are 52-58 carbon atoms in length. The DNA G $+\mathrm{C}$ content of the type strain is $64.4 \mathrm{~mol} \%$.

The type strain, strain OFN S17 ${ }^{\mathrm{T}}\left(=\mathrm{CIP} 109606^{\mathrm{T}}=\mathrm{DSM}\right.$ $44997^{\mathrm{T}}$ ), was isolated from Altamira cave (Cantabria, Spain).

\section{Acknowledgements}

This work received financial support from the Centre National de la Recherche Scientifique (CNRS). The authors acknowledge funding from the Spanish Ministry of Culture for the microbiological study of Altamira Cave and from the Spanish Ministry of Education and Science (project CGL2006-07424). Use of facilities provided by the Museo de Altamira is gratefully acknowledged.

\section{References}

Boiron, P., Provost, F. \& Dupont, B. (1993). Technical protocols. In Méthodes de laboratoire pour le diagnostic de la nocardiose, pp. 107126. Edited by Institut Pasteur. Paris: Institut Pasteur (in French).

Brown-Elliott, B. A., Brown, J. M., Conville, P. S. \& Wallace, R. J. (2006). Clinical and laboratory features of the Nocardia spp. based on current molecular taxonomy. Clin Microbiol Rev 19, 259-282.

Devulder, G., Pierre, G., Baty, F. \& Flandrois, J. P. (2003). BIBI, a bioinformatics bacterial identification tool. J Clin Microbiol 41, 1785-1787.

Felsenstein, J. (1981). Evolutionary trees from DNA sequences: a maximum likelihood approach. $J$ Mol Evol 17, 368-376.

Galtier, N., Gouy, M. \& Gautier, C. (1996). SeaView and PHYLO_WIN, two graphic tools for sequence alignment and molecular phylogeny. Comput Appl Biosci 12, 543-548.

Gonzalez, J. M. \& Saiz-Jimenez, C. (2002). A fluorimetric method for the estimation of $\mathrm{G}+\mathrm{C}$ mol\% content in microorganisms by thermal denaturation temperature. Environ Microbiol 4, 770-773.

Gonzalez, J. M. \& Saiz-Jimenez, C. (2005). A simple fluorimetric method for the estimation of DNA-DNA relatedness between closely related microorganisms by thermal denaturation temperatures. Extremophiles 9, 75-79.

Goodfellow, M. (1992). The family Nocardiaceae. In The Prokaryotes, 2nd edn, pp. 1188-1213. Edited by A. Balows, H. G. Trüper, M. Dworkin, W. Harder \& K. H. Schleifer. New York: Springer.

Goodfellow, M. (1998). Nocardia and related genera. In Topley \& Wilson's Microbiology and Microbial Infections, 9th edn, vol. 2, pp. 462-489. Edited by A. Balows \& B. I. Duerden. London: Arnold.

Goodfellow, M. \& Lechevalier, M. P. (1989). Genus Nocardia Trevisan $1889,9^{\mathrm{AL}}$. In Bergey's Manual of Systematic Bacteriology, vol. 4, pp. 2350-2361. Edited by S. T. Williams, M. E. Sharpe \& J. G. Holt. Baltimore: Williams \& Wilkins.

Groth, I. \& Saiz-Jimenez, C. (1999). Actinomycetes in hypogean environments. Geomicrobiol J 16, 1-8.

Groth, I., Schumann, P., Schuetze, B., Augsten, K., Kramer, I. \& Stackebrandt, E. (1999). Beutenbergia cavernae gen. nov., sp. nov., an
L-lysine-containing actinomycete isolated from a cave. Int $J$ Syst Bacteriol 49, 1733-1740.

Groth, I., Schumann, P., Schütze, B., Augsten, K. \& Stackebrandt, E. (2002). Knoellia sinensis gen. nov., sp. nov. and Knoellia subterranea sp. nov., two novel actinobacteria isolated from a cave. Int J Syst Evol Microbiol 52, 77-84.

Jurado, V., Groth, I., Gonzalez, J. M., Laiz, L. \& Saiz-Jimenez, C. (2005a). Agromyces salentinus sp. nov. and Agromyces neolithicus sp. nov. Int J Syst Evol Microbiol 55, 153-157.

Jurado, V., Groth, I., Gonzalez, J. M., Laiz, L. \& Saiz-Jimenez, C. (2005b). Agromyces subbeticus sp. nov., isolated from a cave in southern Spain. Int J Syst Evol Microbiol 55, 1897-1901.

Jurado, V., Gonzalez, J. M., Laiz, L. \& Saiz-Jimenez, C. (2006). Aurantimonas altamirensis sp. nov., a member of the order Rhizobiales isolated from Altamira Cave. Int J Syst Evol Microbiol 56, 2583-2585.

Kluge, A. G. \& Farris, F. S. (1969). Quantitative phyletics and the evolution of anurans. Syst Zool 18, 1-32.

Kroppenstedt, R. M. (1982). Separation of bacterial menaquinones by HPLC using reverse phase (RP18) and a silver loaded ion exchanger as stationary phases. J Liq Chromatogr 5, 2359-2367.

Kroppenstedt, R. M. (1985). Fatty acid and menaquinone analysis of actinomycetes and related organisms. In Chemical Methods in Bacterial Systematics (Society for Applied Bacteriology Technical Series vol. 20), pp. 173-199. Edited by M. Goodfellow \& D. E. Minnikin. New York: Academic Press.

Kumar, S., Tamura, K. \& Nei, M. (2004). MEGA3: integrated software for molecular evolutionary genetics analysis and sequence alignment. Brief Bioinform 5, 150-163.

Lee, S. D. (2006a). Amycolatopsis jejuensis sp. nov. and Amycolatopsis halotolerans sp. nov., novel actinomycetes isolated from a natural cave. Int J Syst Evol Microbiol 56, 549-553.

Lee, S. D. (2006b). Nocardia jejuensis sp. nov., a novel actinomycete isolated from a natural cave on Jeju Island, Republic of Korea. Int $J$ Syst Evol Microbiol 56, 559-562.

Lee, S. D. (2006c). Actinocorallia cavernae sp. nov., isolated from a natural cave in Jeju, Korea. Int J Syst Evol Microbiol 56, 1085-1088.

Marmur, J. (1961). A procedure for the isolation of deoxyribonucleic acid from microorganisms. J Mol Biol 3, 208-218.

McNeil, M. M. \& Brown, J. M. (1994). The medically important aerobic actinomycetes: epidemiology and microbiology. Clin Microbiol Rev 7, 357-417.

Minnikin, D. E., Alshamaony, L. \& Goodfellow, M. (1975). Differentiation of Mycobacterium, Nocardia, and related taxa by thin-layer chromatographic analyses of whole-cell methanolysates. $J$ Gen Microbiol 88, 200-204.

Minnikin, D. E., O'Donnell, A. G., Goodfellow, M., Alderson, G., Athalye, M., Schaal, A. \& Parlett, J. H. (1984). An integrated procedure for the extraction of bacterial isoprenoid quinones and polar lipids. J Microbiol Methods 2, 233-241.

Orchard, V. A. \& Goodfellow, M. (1980). Numerical classification of some named strains of Nocardia asteroides and related isolates from soil. J Gen Microbiol 118, 295-312.

Rodríguez-Nava, V., Couble, A., Molinard, C., Sandoval, H., Boiron, P. \& Laurent, F. (2004). Nocardia mexicana sp. nov., a new pathogen isolated from human mycetomas. J Clin Microbiol 42, 4530-4535.

Rodríguez-Nava, V., Couble, A., Devulder, G., Flandrois, J.-P., Boiron, P. \& Laurent, F. (2006). Use of PCR-restriction enzyme pattern analysis and sequencing database for $h s p 65$ gene-based identification of Nocardia species. J Clin Microbiol 44, 536-546.

Rodríguez-Nava, V., Khan, Z. U., Pötter, G., Kroppenstedt, R. M., Boiron, P. \& Laurent, F. (2007). Nocardia coubleae sp. nov., isolated 
from oil-contaminated Kuwaiti soil. Int J Syst Evol Microbiol 57, $1482-1486$.

Saitou, N. \& Nei, M. (1987). The neighbor-joining method: a new method for reconstructing phylogenetic trees. Mol Biol Evol 4, 406-425.

Seo, J. P., Yun, Y. W. \& Lee, S. D. (2007). Nocardia speluncae sp. nov., isolated from a cave. Int J Syst Evol Microbiol 57, 2932-2935.

Stackebrandt, E. \& Goebel, B. M. (1994). Taxonomic note: a place for DNA-DNA reassociation and $16 \mathrm{~S}$ rRNA sequence analysis in the present species definition in bacteriology. Int J Syst Bacteriol 44, 846-849.
Staneck, J. L. \& Roberts, G. D. (1974). Simplified approach to identification of aerobic actinomycetes by thin-layer chromatography. Appl Microbiol 28, 226-231.

Thompson, J. D., Gibson, T. J., Plewniak, F., Jeanmougin, F. \& Higgins, D. G. (1997). The CLUSTAL_X windows interface: flexible strategies for multiple sequence alignment aided by quality analysis tools. Nucleic Acids Res 25, 4876-4882.

Ziemke, F., Höfle, M. G., Lalucat, J. \& Rosselló-Mora, R. (1998). Reclassification of Shewanella putrefaciens Owen's genomic group II as Shewanella baltica sp. nov. Int J Syst Bacteriol 48, 179-186. 